\title{
WORK-FAMILY CONFLICT AND EMPLOYEE PERFORMANCE IN GHANA'S BANKING SECTOR
}

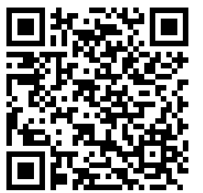

\author{
Dorothy A. Morrison *1凶, John Victor Mensah 2 四 (iD), Gloria Naa Adorkor Kpakpo ${ }^{3}$ \\ , Claudia Asante 4 四 \\ ${ }^{* 1,3,4}$ School of Business, Ghana Institute of Management and Public Administration, Ghana \\ 2 School for Development Studies, University of Cape Coast, Ghana
}

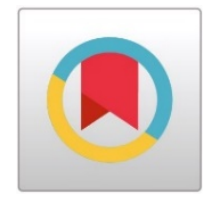

DOI: https://doi.org/10.29121/granthaalayah.v8.i9.2020.1120

Article Type: Research Article

Article Citation: Dorothy A. Morrison, John Victor Mensah, Gloria Naa Adorkor Kpakpo, and Claudia Asante. (2020). WORKFAMILY CONFLICT AND EMPLOYEE PERFORMANCE IN GHANA'S BANKING SECTOR. International Journal of Research GRANTHAALAYAH, 8(9), 113-122. https://doi.org/10.29121/granthaa layah.v8.i9.2020.1120

Received Date: 12 August 2020

Accepted Date: 29 September 2020

Keywords:

Work-Family Conflict

Employee Performance

Banking Sector

Ghana

\section{ABSTRACT}

Studies indicate that in recent times, many working adults have combined family and work roles but they find it difficult to effectively execute their duties. This is due to the fact that these roles are incompatible, and therefore cause work-family conflict which has adverse concerns for both employees and organizations. This study therefore examined effects of work-family conflict on job performance in a selected bank in Ghana. It is a cross-sectional study and it employed the quantitative research method. Simple random and stratified sampling techniques were used to sample 100 respondents and both primary and secondary data were used. The findings revealed that family demand, long working hours and heavy workload were among the reasons for work-family conflict. Flexible time schedule, supervisory support, supportive work environment, and formulation of family friendly policies such as child care services were strategies the bank used to minimise work-family conflict. A significantly negative correlation was established between work-family conflict and job performance showing that high levels of work-family conflict in employees leads to lower job performance. It was recommended that other banks without work-family conflict strategies should emulate the best practices of the study bank to help enhance the performance of their employees.

\section{INTRODUCTION}

Work is seen to be an integral part of life but the key constituents of adult life are family and work (Neerpal \& Barath, 2013; Nordenmark, 2017). In recent times, more adults are entering the workforce and the World Health Organisation (WHO, 2017) maintains that $60-70 \%$ of adult males and $30-60 \%$ of adult females make up the global working population. However, combining family roles and work roles effectively is difficult for many workers (Ernst \& Young, 2015) and since these roles are incompatible, an inter role conflict occurs (Laode et al., 2017). Work-family conflict is therefore explained as an individual perception of pressures from work and family that are difficult to balance (Wang, 2010). Among the causes of work-family conflict are family demands, scheduled works, daily tasks, longer working hours, high work demand, and job inflexibility (Akkas et al., 2015; Laode et al., 2017).

Work-family conflict has adverse concerns for both employees and organizations (Hamid \& Amin, 2014). Among the negative effects are broken marriages/families, lower job satisfaction, increased absenteeism, intentions to leave work (Adisa et al. 2016; Ojha, 2011) and lower job performance (Muganthan, 2013). Mathis and Jackson (2004)

(C) 2020 The Author(s). This is an open access article distributed under the terms of the Creative Commons Attribution License, which permits unrestricted use, distribution, and reproduction in any medium, provided the original author and source are credited. 
indicate that at the work place, employee performance is what an employee does or does not while Waheed (2011) maintains that employee performance means output from work. It can therefore, be inferred from this that the performance of individual employees is critical to the overall success of the organisation in which they work.

To enable employees to perform better, organisations should put in place strategies for managing workconflicts. Among the strategies are eliminating role ambiguities, educating employees on work and family conflicts, and providing supervisory support (Mete et al., 2014; Warokka \& Febrilia, 2015). As more people are entering the paid workforce due to rapid economic growth and development in recent times, the concept of work-family conflict is also receiving a significant interest from researchers across the world (Allen et al., 2015) since the phenomenon is a human resource issue (Wang \& Tsai, 2014).

Even though work-family conflict is a common issue encountered by the majority of employees (Aslam et al., 2011), those in the banking sector face more of work-family conflicts since there are more demands on employees to make the sector competitive which is negatively impacting performance (Sultan \& Akhtar, 2019; Weerasinghe \& Batagoda, 2015). Ghana's banking sector is not an exception because in 2017, the Bank of Ghana directed banks to substantially increase their capital and going forward to achieve this, the two topmost priorities for banks are improvement in business efficiency and service delivery (Price Waterhouse Coopers, 2018). This may imply that employees have to go the extra mile such as dealing with high workload and working for longer hours which may affect their family lives and create work-life conflict which may negatively impact their job performance. Since one of the most essential sectors that immensely contribute to the development and growth of economies of nations is the banking sector (Ofosu-Hene \& Amoh, 2016), its employees should be helped to manage work-life conflict to enable them give optimum performance to facilitate the achievement of organisational goals.

Since most studies on work-family conflict have come from the developed countries (Aycan, 2008), a great need is seen for more empirical research on work-family conflict in developing countries (Karatepe, Kilic \& Isiksel, 2008). In Ghana, the few researches that have been conducted on work-life conflict have not looked at the effects of worklife conflict on employee performance in the banking industry. For instance, Kissi-Abrokwah et al., (2015) research examined work-life conflict among female bankers, Ametorwo (2016) focused on work-life conflict among female entrepreneurs, while Gamor et al., (2018) centerd their work on the factors of work-family conflict in the hospitality industry.

Guided by the role theory, this paper fills the gap by examining the relationship between work-family conflict and employee performance using a selected bank in Ghana as a case. The specific objectives of the paper are to: (a) explore the causes of work-family conflict in the bank; (b) examine the strategies for managing work-family conflict; and (c) determine the link between work-family conflict and employee performance. The hypothesis formulated for the paper is $\mathrm{H}_{1}$ : Work-family conflict negatively impacts on employee performance.

Since there is limited research on work-family and performance in the banking industry, the findings of this study would add to the empirical literature. This study would also inform management of the selected bank to have a clear view of the impact of work-family conflict in the bank and help its employees to balance work and family roles to enhance their job performance. Additionally, findings from this paper would provide a guide to policy makers in designing and implementing policies that would minimise work-family conflict in the banking industry. Finally, the best practices of strategies being adopted by the bank could be emulated by other banks to help enhance their employees' performance. The paper is organised into five sections: introduction, literature review, study context and methods, results and discussion, and conclusion and recommendations.

\section{LITERATURE REVIEW}

This section reviews related literature to the topic which include the role theory, the concept of work-family conflict, its causes and consequences on employees, strategies for managing work-family conflict and the concept of employee performance. In addition, the link between work-family conflict and job performance, empirical studies on work-family conflict and employee performance, and the conceptual framework for the study are presented.

\subsection{ROLE THEORY}

The literature indicates that several theories are used to explain the concept of work-family conflict such as social exchange theory, theory of interdependence, social identity theory and role theory with role theory 
dominating (Mugunthan, 2013). Kahn et al., (1964) opined that roles are the result of expectations of others about the right behaviour of those in a particular position. The role theory has the basic assumptions that multiple roles lead to role ambiguity, overload, and stress. Different expectations are demanded from people performing different roles and the contradictory expectations within a role can lead to intra-role conflict. Additionally, the pressures from one role can interfere with pressures from the others, leading to overload and physical and psychological stress which can negatively affect the wellbeing of the role performers (Hall \& Hall, 1982).

\subsection{THE CONCEPT OF WORK-FAMILY CONFLICT}

Literature indicates that the concept of work-family conflict was first proposed by Kahn et al. (1964) and they explained it as the pressure coming from family and work roles because of one's inability to fulfil the demands of both roles (cited in Lin et al., 2015). To Wang (2011), work-family conflict is subjective perception of pressures from work and family that are difficult to balance. Work-family conflict is also referred to as work-family interference and negative spill over (Gilham, 2012). Whenever people's home roles conflict with their duties at the workplace, workfamily conflict occurs (Laode et al., 2017). From the views of French et al., (2018), work-family conflict is when work meddles with the capacity to fulfil family needs or family meddles with the capacity to satisfy work needs. Sultan and Akhtar (2019) opined that work-family conflict is when there is a struggle between work and family domains. It can be inferred from the various definitions that work-family conflict centres on the difficulty employees have in fulfilling both work and family duties.

\subsection{CAUSES OF WORK-FAMILY CONFLICT}

Literature puts forward a number of causes of work-family conflict. For instance, in the views of Adriel (2013), work stress strongly correlates to work-family conflict. Akkas et al., (2015) indicate unsupportive family members, long working hours, job inflexibility, work overload, discrimination at workplace, and inadequate supervisory support as causes of work-family conflict. Adisa et al. (2016) outlined work pressure, overwhelming family demands, and an absence of appropriate and practicable work-family balance strategies as causes. While Ee et al. (2017) maintain that excess work and role ambiguity lead to work-family conflict, Laode et al. (2017) mentioned factors that leave no time for leisure due to scheduled work, daily tasks and overtime.

\subsection{CONSEQUENCES OF WORK-FAMILY CONFLICT}

Several studies have been conducted on the effects of work-family conflict on employees, their organisations in which they work and their families (Ojha, 2011). Regarding the individuals, work-family conflict affects their psychological and physical well-being which leads to stress (Frone, 2000). Perceived work-family conflict can also cause uneasiness and burnout (Ojha, 2011) and these can cause absent mindedness in an employee. Work-family conflict also impacts the wellbeing of families by negatively affecting the marital, family and life satisfactions (Brough et al., 2005). These negative consequences on the family can lead to child delinquencies and broken marriages (Adisa et al., 2016). At the organizational level, work-family conflict brings about lower job satisfaction, increased absenteeism, burnout, unhappy workforce and lower performance (Ojha, 2011; Dwijayanti \& Riana, 2018).

\subsection{STRATEGIES FOR MANAGING WORK-FAMILY CONFLICT}

A number of strategies to help manage work-family conflict have been suggested in the literature. First, organisations should educate employees on the realities of work-family conflicts and how to manage them, clearly define employees' roles and give employees roles that they can effectively execute (Mete et al., 2014). Second, flexible working schedule and supportive working environment can help minimise work-family conflict (Warokka \& Febrilia, 2015). Third, supervisory support should be provided to employees to help reduce work-family conflict (Sultan \& Akhtar, 2019). Fourth, institutions should show gratitude to employees who perform their roles efficiently and go the extra mile (Dwijayanti \& Riana, 2018). However, it should be noted that strategies for managing work-family conflicts are circumstantial and as a result, care should be taken to employ the right strategy for the right situation to help achieve positive results (Pillay, 2013). 
Work-Family Conflict and Employee Performance in Ghana's Banking Sector

\subsection{EMPLOYEE PERFORMANCE}

Different authors have different explanations for the concept of employee performance. For instance, Mathis and Jackson (2004) indicate that at the work place, employee performance is what an employee executes or does not execute. Kerns (2008) posits that employee performance is about the achievement of activities that lead to important outcomes. Dar et al. (2011) opined that job performance focuses on how an employee makes effective use of resources to achieve the responsibilities given to him/her. The concept also means output from work (Waheed, 2011). Employee performance is whether an individual completes his/her work well or not (Balouch \& Hassan, 2014). Thus, from the literature, employee performance can be seen as exhibited behaviour in executing a task or the result/outcome or an output of a task. The paper therefore examined how work-family conflict affects employees' behaviour, the result of their jobs as well as the output of their duties at the workplace.

\subsection{STUDIES ON WORK-FAMILY CONFLICT AND EMPLOYEE PERFORMANCE}

Several studies have looked at the link between work-family conflict and employee performance. For instance in a qualitative study, Warokka and Febrilia (2015) examined the relationship between work-family conflict and employee performance in four Indonesian banks, using a sample size of 334 dual-roles women. The findings indicated a significant negative link between work-family conflict and employee performance. Apodiari and Lasisi (2016) studied the effect of work-family conflict on employee performance among female bankers in the Federal Capital Territory in Abuja, Nigeria. It was a descriptive study that involved 920 employees from selected banks and employed the quantitative approach to gather data. The study revealed that work-family role conflict leads to low job performance.

Dwijayanti and Riana (2018) examined the effect of work-family conflict on job performance among 46 civil servants in Indonesia. This quantitative study used descriptive and inferential analysis with partial least square to test the hypotheses. The study found that work-family conflict has a significant negative effect on employee performance. Furthermore, Sultan and Akhtar (2019) conducted a quantitative study on the relationship between work-family conflict and job performance. The quantitative data collected from 100 banking employees were analysed using frequency, percentage, mean, standard deviation and correlation analysis. It was reported that workfamily conflict had significant negative impact on employee performance.

\subsection{CONCEPTUAL FRAMEWORK FOR THE STUDY}

A conceptual framework is a set of all-encompassing concepts and principles from relevant fields of enquiry used to structure a subsequent presentation (Kombo \& Tromp, 2006). It links variables used in a study. The conceptual framework for the study as illustrated in Figure 1 shows the relationship between work-family conflict and employee performance. It explains that as employees perform dual roles i.e. workplace and family roles, there is the possibility for the workplace roles to conflict with the family demands. The employees will also experience longer working hours, work overload, no leisure and role ambiguity.

From the assumptions of role theory, the causes have consequences such as poor mental wellbeing, burnout, and absent mindedness on the one performing the dual roles. Providing managing strategies such as organising workshops on how to handle work-family conflicts, supervisory support and flexible working schedule can enable the employee to be efficient on the work and increase output. On the other hand, the absence of the strategies may lead to inferior work, inefficiency and decreased output, thereby negatively impacting employee performance. 
Dorothy A. Morrison, John Victor Mensah, Gloria Naa Adorkor Kpakpo, and Claudia Asante

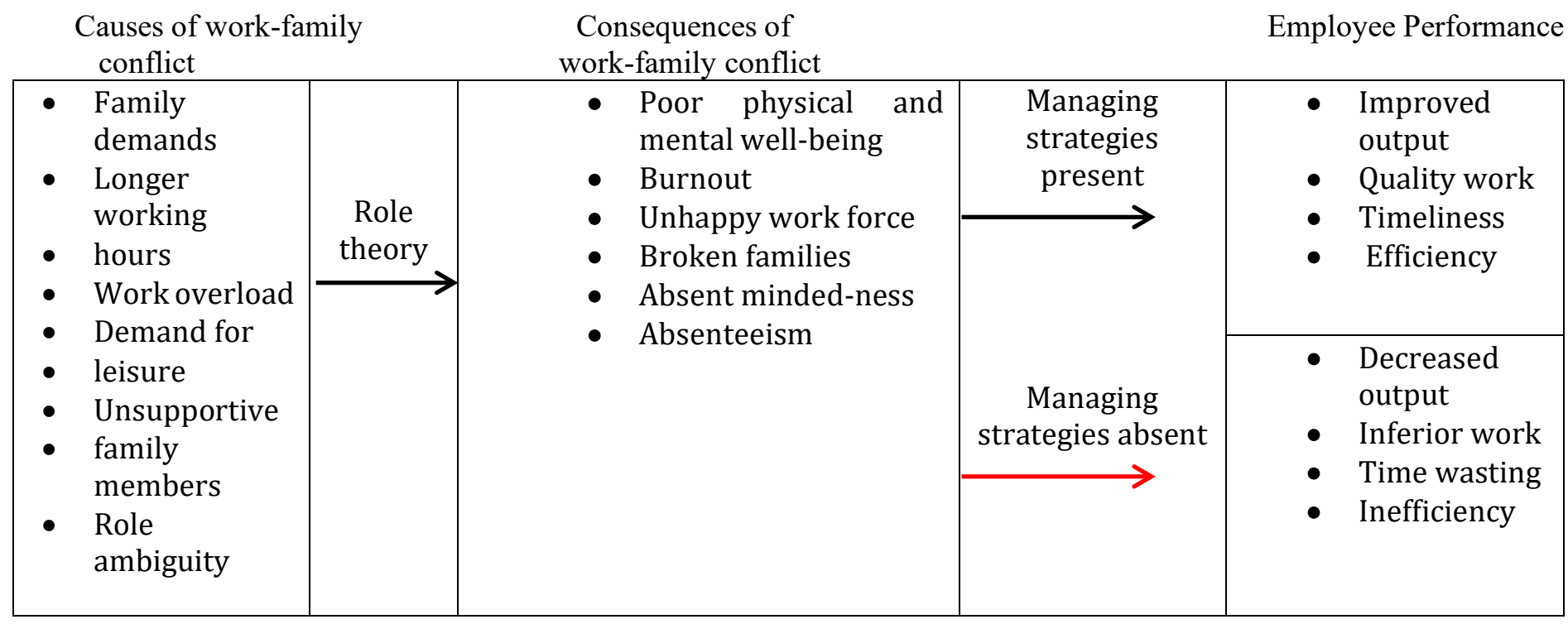

Figure 1: Relationship between work-family conflict and employee performance

Source: Authors' Construct (2020)

\section{STUDY CONTEXT AND METHODS}

At the start time of the study, the Ghanaian banking sector consisted of 34 licensed banks; 17 classified as domestically-controlled, while the remaining 17 were foreign-controlled (Bank of Ghana, 2018). The selected bank, a domestically-controlled one, was established in 1995, became a full-scale commercial bank in 2011 and has over 20 years' experience in Ghana. Its mission is to provide superior financial solutions and create value for its stakeholders, and has the vision of becoming a global bank out of Ghana. The core values of the bank are summarized in the acronym I-CARE, which stands for Integrity, Customer centric, Agile, Resilience and Excellence which serves as a constant reminder about what their priorities are on a daily basis. The Bank has won several awards including "Best Bank, Customer Care \& Advisory Services" in 2012 and "Best Bank, Enterprise Financing" in 2013. At the time of the study, the selected bank had thirty-seven (37) branches across the country with 600 permanent employees and customer base of 107,076.

The study was conducted in five branches of the bank in the national capital, Accra. A cross-sectional survey design was used based on the quantitative approach to data collection and analysis. The data were drawn from primary and secondary sources. The secondary sources included the bank's annual reports, newsletters, manuals, journals and textbooks. Out of the total 359 permanent employees from the selected five branches, 100 were sampled for the study and they were from legal, human resource, operations, IT, corporate communication and marketing departments. To ensure representativeness, $30 \%$ of the population of 359 was taken as the sample using Nardi's (2003) guidelines.

In line with the specific objectives of the study, the questionnaire was structured into four parts: respondents personal information, causes of work-family conflict, strategies for managing work-family conflict and the relationship between work-place conflict and employee performance. The written informed consent assured the respondents anonymity and confidentiality. The field data collection period was from $20^{\text {th }}$ February to $30^{\text {th }}$ April, 2020. Out of the 100 questionnaires given out, 83 were filled and returned which represented $83 \%$ response rate. The Statistical Product and Service Solutions (SPSS) version 25 was used to analyse the data.

\section{RESULTS AND DISCUSSION}

The results obtained from the data are presented and discussed based on the specific objectives of the paper. 


\subsection{RESPONDENTS' PERSONAL INFORMATION}

This section presents the sex, age, marital status, educational background and the number of years respondents had worked with the bank. The majority (53.0\%) of the respondents were males and $47.0 \%$ were females, $66.3 \%$ were in the 25-44 years age range, 59.0\% were not married, 63.9\% have had at least Bachelor's Degree and $47(56.7 \%)$ have worked with the bank between one and ten years.

\subsection{EMPLOYEES' PERCEPTION OF WORK-FAMILY CONFLICT AND CAUSES}

The paper explored the respondents' perception on work-family conflict and the majority (66.2\%) indicated that the phenomenon exists. The respondents were asked to indicate the major causes of work-family conflict and their responses are shown in Table 1 . The majority of the respondents agreed that family demands, longer working hours, heavy workload and unsupportive family members are among the major causes of work-family conflict. Specifically, $67.5 \%$ of the respondents agreed that family demand caused work-family conflict while $32.5 \%$ disagreed; $57.8 \%$ agreed that longer working hours caused work-family conflict and $42.2 \%$ disagreed; and $81.9 \%$ affirmed that heavy workload is a cause of work-family conflict with $18.1 \%$ being in the negative.

Table 1: Causes of work-family conflict

\begin{tabular}{|c|c|c|c|c|c|}
\hline Causes & Response & Frequency & Percent & Mean & Rank \\
\hline Family demands & Yes & 56 & 67.5 & 1.67 & 3 \\
& No & 27 & 32.5 & & \\
\hline Long working hours & Yes & 48 & 57.8 & 1.58 & 4 \\
& No & 35 & 42.2 & & \\
\hline Demand for leisure & Yes & 39 & 47.0 & 1.47 & 5 \\
& No & 44 & 53.0 & & \\
\hline Heavy workload & Yes & 68 & 81.9 & 1.82 & 2 \\
& No & 15 & 18.1 & & \\
\hline Unsupportive family members & Yes & 74 & 89.2 & 1.89 & 1 \\
& No & 9 & 10.8 & & \\
\hline
\end{tabular}

Sample $(\mathrm{n})=83$

Source: Field Survey, 2020

Additionally, 89.2\% respondents agreed that having unsupportive family members is a cause of work-family conflict with only $10.8 \%$ disagreeing to the assertion that unsupportive family members is the major cause of workfamily conflict. However, the majority $53.0 \%$ of the respondents did not agree to fact that the demand for leisure time is a reason for work-family conflict.

Table 1 shows that "unsupportive family members" $(\mathrm{M}=1.89)$, "heavy workload" $(\mathrm{M}=1.82)$, and "family demand" $(M=1.67)$ were the first three major causes of work-family conflict experienced by the respondents. It also reflects that demand for leisure time is the least cause of work-family conflict $(M=1.47)$. These findings confirm similar findings of Akkas (2015), Adisa et al., (2016), Gamor et al., (2014) and Ee et al., (2017) that long working hours, inadequate family support, work overload and family demands are the major causes of work-family conflict.

\subsection{STRATEGIES FOR MANAGING WORK-FAMILY CONFLICT}

The respondents were asked to indicate four major strategies that are provided by the bank to help employees manage work-family conflict and their responses mentioned are shown in Table 2. 
Dorothy A. Morrison, John Victor Mensah, Gloria Naa Adorkor Kpakpo, and Claudia Asante

Table 2: Strategies for managing work-family conflict

\begin{tabular}{|c|c|c|c|c|c|}
\hline Strategies & Response & Frequency & Percent & Mean & Rank \\
\hline Family friendly policies & Yes & 69 & 83.1 & 1.83 & 1 \\
& No & 14 & 16.9 & & \\
\hline Flexible time schedule & Yes & 59 & 71.1 & 1.71 & 2 \\
& No & 24 & 28.9 & & \\
\hline \multirow{2}{*}{ Supportive work environment } & Yes & 51 & 61.4 & 1.61 & 3 \\
& No & 32 & 38.6 & & \\
\hline Supervisory support & Yes & 48 & 57.8 & 1.58 & 4 \\
& No & 35 & 42.2 & & \\
\hline
\end{tabular}

$\mathrm{n}=83$

Source: Field Survey, 2020

About $83.1 \%, 71.1 \%, 61.4 \%$ and $57.8 \%$ of the respondents indicated family friendly policies, flexible time schedule, supportive working environment and supervisory support respectively. Having family friendly policies such as special leave for maternity and child issues would enable employees to perform their work place roles effectively to prevent burnout. For instance, the child issue policy would allow employees who have children below three years to close earlier to attend to them if needed. Respondents explained that having flexible work schedule at the workplace would enable employees perform both work and family roles effectively without pressure and adequate supervisory support such as coaching and feedback could help employees to be task efficient and be free from stress.

Table 2 also shows that the ranked strategies are in the following descending order: family friendly policies (Mean=1.83), flexible time schedule (Mean=1.71), supportive working environment (Mean=1.61) and supervisory support (Mean=1.58). These findings therefore support the studies of Warokka and Febrilia (2015) and Sultan and Akhar (2019) that flexible working schedule, supportive working environment and supervisory support play an important role in minimising work-family conflict.

\subsection{WORK-FAMILY CONFLICT AND EMPLOYEE PERFORMANCE}

Literature shows that work-family conflict has effect on performance. Respondents were therefore asked to indicate their perceived effect of work-life conflict on employee performance and Table 3 reveals their responses.

Table 3: Perceived effect of work-life conflict on employee performance

\begin{tabular}{|c|c|c|}
\hline Perceived Effects & Frequency & Percent \\
\hline Positive & 13 & 15.7 \\
\hline Negative & 70 & 84.3 \\
\hline Total & 83 & 100.0 \\
\hline
\end{tabular}

Source: Field Survey, 2020

The majority (84.3.0\%) of the respondents indicated negative effects while only $15.7 \%$ indicated positive effects. Among the explanations for the negative effects of work-family conflict on employee performance was the fact that family demands interfered with work-related activities. They also explained that sometimes because employees were anxious about the unperformed family role, there was the tendency to become absent-minded on the job. This could lead to poor quality of work, wasting time on one activity which eventually reduced work output. These findings affirm the studies of Apodiari and Lasisi (2016) and Dwijayanti and Riana (2018) that work-family conflict has negative effects on employee performance.

A Spearman rank order correlation was conducted to statistically examine the direction and strength of the relationship that exists between work-family conflict and employee performance and this is shown in Table 4. 
Work-Family Conflict and Employee Performance in Ghana's Banking Sector

Table 4: Spearman's correlation between work-family conflict and job performance

\begin{tabular}{|c|c|c|c|}
\hline Variable & Correlation coefficient & 1 & 2 \\
\hline Work-family conflict & $\begin{array}{c}\text { Rho } \\
\text { Sig. (2-tailed) }\end{array}$ & 1.000 & $-0.507^{* *}$ \\
\hline Employee performance & $\begin{array}{c}\text { Rho } \\
\text { Sig. (2-tailed) }\end{array}$ & $-0.507^{* *}$ & 1.000 \\
\hline
\end{tabular}

$\mathrm{n}=83 ; \quad{ }^{* *}$ Correlation coefficient is significant at 0.01 level.

Source: Field Survey, 2020

The result indicates a significantly negative correlation between work-family conflict and employee performance ( $r h o=-0.507 ; p<0.01$ ). Cohen (1988) maintains that a rho value of $0.10-0.29$ is small, $0.30-0.49$ is medium and 0.50-1.0 is large. The rho value therefore shows a large correlation result, meaning that the higher the level of work-family conflict experienced by employees, the lower their job performance. The conclusion is that the test revealed a statistically significant and negative relationship between work-family conflict and employee performance and therefore, the hypothesis for the study was accepted.

\section{CONCLUSIONS AND RECOMMENDATIONS}

Based on the specific objectives of the paper, it is concluded that among the causes of work-life conflict are family demands, longer working hours, work overload and unsupportive family members. Second, the bank employed strategies to help its employees manage work-family conflicts and these strategies included flexible work schedule, supervisory support, supportive work environment and family friendly policies. Third, there was a significantly strong negative relationship between work-family conflict and employee performance. Based on conclusions, it is recommended that other banks in Ghana which do not have strategies for managing work-family conflict should either adopt the strategies of the study bank or formulate their own to help enhance employee performance.

\section{SOURCES OF FUNDING}

This research received no specific grant from any funding agency in the public, commercial, or not-for-profit sectors.

\section{CONFLICT OF INTEREST}

The author have declared that no competing interests exist.

\section{ACKNOWLEDGMENT}

None.

\section{REFERENCES}

[1] Adisa, T. A., Osabutey, E., \& Gbadamosi, G. (2016). Understanding the causes and consequences of work-family conflict: An exploratory study of Nigerian employees. Employee Relations, 38(5), 770-788. https://doi.org/10.1108/ER-11-2015-0211 (Accessed 20 January, 2020).

[2] Adriel, K. S. (2013). Work-family enrichment and job-family satisfaction among hotel employees. World Applied Sciences Journal, 22(12), 1775-1781.

[3] Akkas, M. A., Hossain, M. I., \& Rhaman, S. (2015). Causes and consequences of work-family conflict (WFC) among the female employees in Bangladesh: An empirical study. Journal of Business and Economics, 6(12), 2063-2071. https://doi.org/10.15341/jbe(2155-7950)/12.06.2015/007 (Accessed 3 March, 2020)

[4] Allen, T. D., French, K. A., Dumani, S., \& Shockley, K. M. (2015). Meta-analysis of work-family conflict mean differences: Does national context matter? Journal of Vocational Behaviour, 90(4), 90-100. 
Dorothy A. Morrison, John Victor Mensah, Gloria Naa Adorkor Kpakpo, and Claudia Asante

[5] Ametorwo, A. M. (2016). Managing work family conflict among female entrepreneurs in Ghana for development. International Journal of Economics, Business and Management Studies, 3(1), 21-35.

[6] Apodiari, U., \& Lasisi, R. (2016). Work-family conflict and job performance among women bankers in the Federal Capital Territory, Abuja, Nigeria. International Journal of Development and Management Review, 11(1), 103-119.

[7] Aslam, R., Shumaila, S., Azhar, M., \& Sadaqat, S. (2011) Work-family conflicts: Relationship between work-life conflict and employee retention - A comparative study of public and private sector employees. Interdisciplinary Journal of Research in Business, 1(2), 18-29.

[8] Aycan, Z. (2008). Cross-cultural perspectives to work-family conflict, in K. Korabik \& D. Lero (eds.), Handbook of Work-Family Conflict, London: Cambridge University Press.

[9] Bank of Ghana (2018). Banking sector report https://www.bog.gov.gh/wpcontent/uploads/2019/08/Banking-Sector-Report-July-2018-1.pdf (Accessed 23 March 2020).

[10] Brough, P., O'Driscoll, M. P., \& Kalliath, T. J. (2005). The ability of 'family friendly' organisational resources to predict work-family conflict and job and family satisfaction. Stress and Health: Journal of the International Society for the Investigation of Stress, 21(4), 223-234.

[11] Dwijayanti, K. I., \& Riana, I. G. (2018). The effect of work-family conflict on job satisfaction and employee performance. Journal of Multidisciplinary Academic, 2(1), 20-23. https://doi.org/2541 - 0369/2613 - 988X (Accessed 17 January 2020).

[12] Ee, M. J. Y. C., Teoh, W. M.-Y., \& Yen, Y. Y. (2017). Role conflict, role ambiguity and role overload: The strains of work-family conflict. The Social Sciences, 12(9), 1566-1576.

[13] Ernst, F., \& Young, W (2015). Global generations: A global study on work-life challenges across generations. Retrieved from http://EY-global-generations-a-global-study-on-work-life-challenges-acrossgenerations.pdf. Accessed on September 9, 2019.

[14] Frone, M. R. (2000). Work-family conflict and employee psychiatric disorders: The national comorbidity survey. Journal of Applied Psychology, 85(6), 888-895.

[15] French, K. A., Dumani, S., Allen, T. D., \& Shockley, K. M. (2018). A meta-analysis of work-family conflict and social support. Psychological Bulletin, 144(3), 284-314. https://doi.org/10.1037/bul0000120.A (Accessed 17 November 2019).

[16] Gamor, E., Amissah, E. F., Amissah, A., \& Nartey, E. (2018). Factors of work-family conflict in the hospitality industry in Ghana. Journal of Human Resources in Hospitality and Tourism, 17(4), 482-501.

[17] Hall, D.T. \& Hall, F.S. (1982). Stress and the two career couple. In C.L. Cooper \& R. Payne (eds.). Current concerns in occupational stress (pp.254-266), New York: Wiley.

[18] Hamid, R. A., \& Amin, S. M. (2014). Work-family conflict and work-family enrichment and their consequences in Malaysia. Middle-East Journal of Scientific Research, 19(5), 729-733.

[19] Kahn, R.L., Wolfe, D.M., Quinn, R.P., Snoek, J.D. \& Rosenthal, R.A. (1964). Organizational stress: Studies in role conflict and ambiguity, New York: Wiley.

[20] Karatepe, O. M., Kilic, H., \& Isiksel, B. (2008). An examination of the selected antecedents and outcomes of work-family conflict and family-work conflict in frontline service jobs. Services Marketing Quarterly, 29(4), $1-24$.

[21] Kissi-Abrokwah, B., Andoh-Robertson, T., Tutu-Danquah, C. \& Agbesi, C.S. (2015). Examining work and family conflict among female bankers in Accra Metropolis, Ghana. Journal of Education and Practice, 6(1), 61-68 www.iiste.org Accessed on September 9, 2019.

[22] Kombo, K. D., and Tromp, L. A. (2006). Proposal and thesis writing: An introduction. Nairobi: Paulines Publications Africa.

[23] Laode, A. A., Nur, N., Taufik, H. M., Sabara, G. T., Rosmawaty, Kartini, \& Mirad. (2017). The influence of work family conflict and work stress on employee performance. International Journal of Management and Applied Science, 3(2), 1- 6.

[24] Lin, W.-R., Chen, H.-M., \& Sun, C.-K. (2015). A study on the relationship between work-family conflicts and the job satisfaction of tour leaders. Journal of Tourism and Recreation, 2(1), 41-52. https://doi.org/10.12735/jotr.v2i1p41

[25] Mete, M., Ünal, Ö. F., \& Bilen, A. (2014). Impact of work-family conflict and burnout on performance of accounting professionals. Procedia - Social and Behavioral Sciences, 131, 264-270. https://doi.org/10.1016/j.sbspro.2014.04.115 
[26] Mugunthan, S. (2013). A study of work-family conflict and job satisfaction. International Journal of Social Science \& Interdisciplinary Research, 2(7), 1-12.

[27] Nardi, P.M. (2003). Doing survey research: A guide to quantitative methods. Boston, MA: Allyn and Bacon.

[28] Neerpal, R. \& Barath, M. (2013). Work-family conflict and job and family satisfaction: Moderating effect of social support among police personnel. Equality, Diversity and Inclusion: An International Journal, 32(4), 438454.

[29] Nordenmark, M. (2017). The importance of job and family satisfaction for happiness among women and men in different gender regimes. Societies, 8(1), 56-63.

[30] Ofosu-Hene, E.D., \& Amoh, P. (2016). Risk management and performance of listed banks in Ghana. European Journal of Business Science and Technology, 2(2), 107-21.

[31] Pillay, D. (2013). Exploring the mediating role of coping in the work-family conflict and job strain relationship: A study of female educators in schools across the iLembe region. University of KwaZulu-Natal.

[32] Price Waterhouse Coopers (2018). Having secured the new capital; what next for banks? www.pwc.com/gh (Accessed 20 March 2020).

[33] Sultan, F., \& Akhtar, S. H. (2019). Impact of work family conflicts on employee performance with moderating role of supervisor support in banking sector of KPK, Pakistan. Language in India, 19(6), 72-79.

[34] Wang, F. (2011). The mediation effect of work-family conflict on the relationship between work/family demands and OCB: A study in China. Tilburg University.

[35] Wang, M. L., \& Tsai, L. J. (2014). Work-family conflict and job performance in nurses: The moderating effects of social support. Journal of Nursing Research, 22(3), 200-207. https://doi.org/10.1097/jnr.0000000000000040 Accessed 23 February 2020)

[36] Warokka, A., \& Febrilia, I. (2015). Work-family conflict and job performance: Lesson from a Southeast Asian emerging market. Journal of Southeast Asian Research, 2015, 1-14. https://doi.org/10.5171/2015.420802

[37] Weerasinghe, K. P. N. N., \& Batagoda, C. K. (2015). The impact of work family conflicts on employee job satisfaction: An investigation of employees in private sector banks in Kandy District, Sri Lanka. Human Resource Management Journal, 3(1), 10-17.

[38] World Health Organisation (2017). Depression and other common mental disorders: Global health estimates. $\begin{array}{llllll}\text { Accessed on } & \text { January } & 1020 . & \text { Retrieved }\end{array}$ http://apps.who.int/iris/bitstream/handle/10665/254610/WHOMSD?sequence=1. 